\title{
Renewable Energy in Portugal - Legislation, Incentives and Suggestions
}

\author{
M. Fernanda T. Moreira, Júlio S. Martins and João L. Afonso \\ Department of Industrial Electronics \\ University of Minho \\ Campus de Azurém - 4800-058 Guimarães (Portugal) \\ phone: +351 253 510191, fax: +351 253510189 \\ e-mail: moreira_fernanda@portugalmail.pt,jmartins@dei.uminho.pt, jla@dei.uminho.pt
}

\begin{abstract}
This paper presents the evolution of renewable energy generation in Portugal in the last decade, and explains the legislation and incentives in existence. The paper also presents suggestions that could incentive small and medium consumers to install renewable energy power plants (namely of wind power and photovoltaic types) in their facilities. These power plants would have to accomplish present legislation regarding "reactive energy" production during peak power consumption period, and besides, would have to assure power quality levels. On the other hand, reversible energy meters should be used, so that it would be registered the consumption of energy from the energy company, or the delivery of energy to the energy company. The equipments which could implement these characteristics are briefly described.
\end{abstract}

\section{Key words}

Renewable Energy, Wind Power Energy, Photovoltaic Energy, Distributed Generation, Reversible Energy Meter.

\section{Introduction}

In Portugal, the external energy dependence is very high. In the 90's we have imported more than $80 \%$ of all consumed primary energy. At present, there is no any record regarding to the exploration of any energetic product with fossil origin. For that reason, the renewable energy production has a very important role, because it represents all the domestic energy production. Portugal is the fourth country of European Union (EU) with the highest percentage of renewable energy utilisation, with $40 \%$ of all used energy.

The renewable energy sources contain a set of technologies with different levels of development. Some, like the hydro energy, the wind energy and the biomass energy, have already reached a high level of maturity, being commercially competitive, in certain conditions, with conversion equipment of fuel fossil. Nowadays, almost all renewable energy produced in Portugal comes from hydroelectric power plants. Biomass energy has also an important contribution. In the last years, wind energy utilisation has registered a strong increment, and now performs a significant role.

Figure 1 presents the electrical energy production in Portugal between the years 1990 and 2000. It can be seen that the production is clearly based on thermal and hydro power plants (data source: DGE - Direcção Geral de Energia). In the year 2000, the geothermal and wind energy production represented less than $0.6 \%$ of the total electrical energy production, although it is predictable an important increase in the next years.

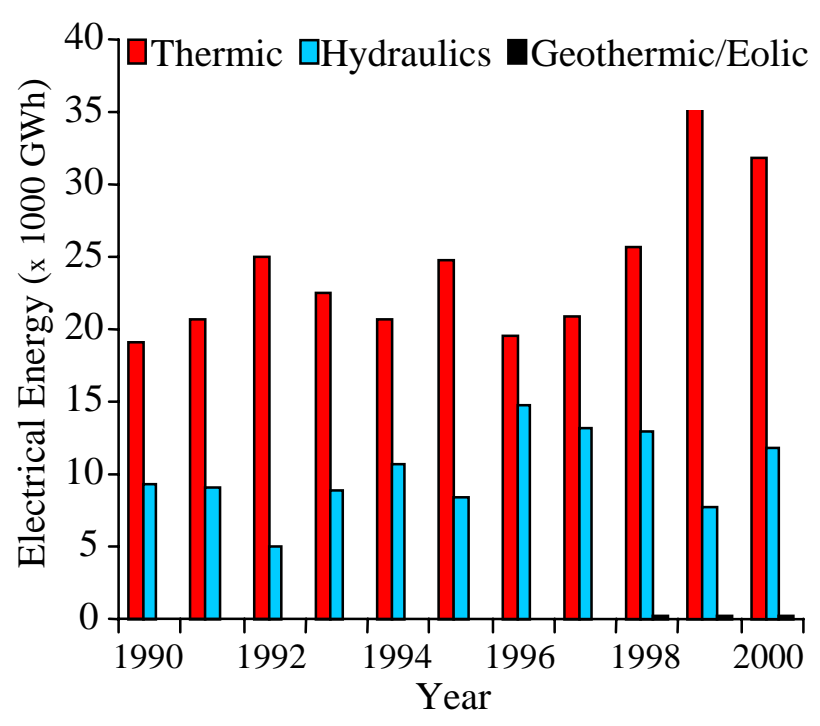

Fig. 1. Electrical energy production in Portugal from 1990 to 2000.

To solve the challenge of increasing energy production from renewable energy sources in Europe, it is necessary a common effort involving the European Community and its member States. If in the next decade our community cannot satisfy a higher share of electrical energy necessities using renewable energy, an important development opportunity will be lost, and it will be more difficulty for each country to comply the established compromises at European and international level regarding to environmental protection. 
The renewable energy source development can contribute as an active form to the creation of work positions, principally in small and medium enterprises, which have an enormous importance in the European community.

Figure 2 presents foreseen data for the years 2005 and 2010 regarding electrical energy production in Portugal. The prevision of DGE aims that in the year 2010 about $1.6 \%$ of the total electrical energy production will have source in geothermal and wind energy, without any reference on solar energy. It is important to note that, from 2005 to 2010 DGE previsions show a rise in the contribution of thermal power plants from $74.9 \%$ to $77.7 \%$ of the total electrical energy production.

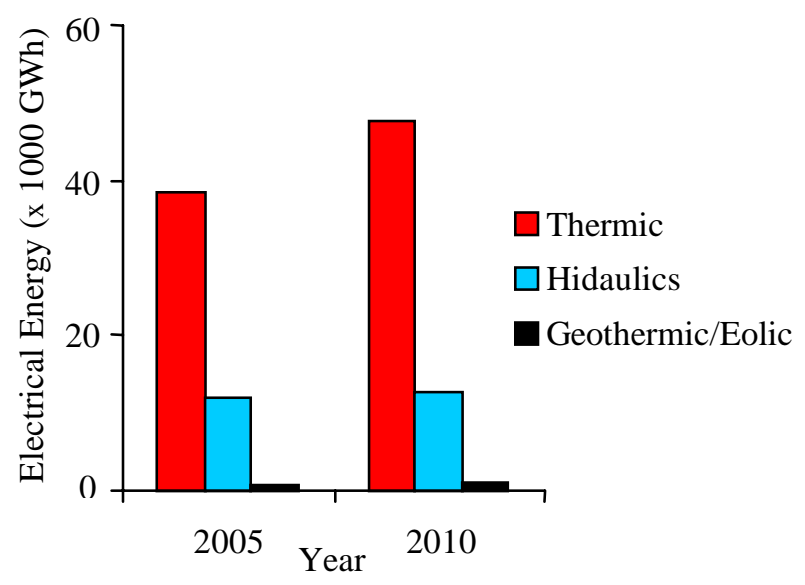

Fig. 2. Prevision of electrical energy production for the years 2005 and 2010 in Portugal.

The production of electrical energy using fossil fuel, or the co-generation production, using industrial residues, are pollutant ways, which should be used only as last resource.

Portugal is totally dependent on other countries in relation to fossil fuel consumption, and specially regarding to petrol.

The external dependency to obtain energy is not a good basis for the future, since the country remains very dependent of international conjectures. Wind, solar, hydro, tide and maritime wave energies are renewable non-pollutants sources of energy, and can be produced in Portugal.

\section{Portuguese Legislation Applicable to Renewable Energy}

Many times the lack of information about legislation may difficult the initiatives to develop efforts in the areas of renewable energy sources and environment improvement. The Portuguese legislation related to renewable energy production is presented next [1]-[14]:

\section{A. Dispatch n. $22044 / 2002$ ( $2^{\text {nd }}$ series) of September}

(Published in: "Diário da República no 198/2001, Série II, Ministério da Indústria e Energia”)
For candidate projects to program MAPE ("Medida de Apoio ao Aproveitamento do Potencial Energético e Racionalização de Consumos”), which candidatures come to be presented during 2003, will invigorate the applicable reference values, published in governmental order n. 383/2002 of 10th April, with exception to the values applicable to co-generation's power plants with power up to $10 \mathrm{MW}$, of which reference value is $€ 1000 / \mathrm{kW}$ and to co-generation's power plants with power higher than $10 \mathrm{MW}$, of which reference value is $€ 1100 / \mathrm{kW}$.

\section{B. Governmental Order n. 764/2002 of 1st July}

(Published in: “Diário da República n 149/2002, Série I B, Ministério da Indústria e Energia)

Electrical energy production - Low Voltage - Tariffs Establishes the applicable tariffs to electrical energy production plants in low voltage, licentiate under the cover of Decree-Law n. 68/2002 of 25th March, as well as the dispositions concerning to the period of modality's validity of the same tariffs.

\section{Despatch n. 9148/2002 of 15th of April}

(Published in: “Diário da República n 103/2002, Sériel II, Ministério da Indústria e Energia”)

Public service electrical system - Electro-producers Independent electrical system - Electrical energy reception - Reception points - Electrical system for public supply - Clarifies the interpretation of predictable procedures of Decree-Law n. 312/2001 of 10th December, relating to the attribution requests instructions of the electrical energy reception point.

\section{Governmental Order n. 383/2002 of 10th April}

(Published in: “Diário da República nº 84/2002, Série I-B, Ministério da Indústria e Energia”)

Regulation for execution of MAPE, which has the objective of propitiating support to electrical and thermal energy production, with resource to new renewable energies types, to the energy rational utilisation of energy, and to the conversion to natural gas consumption.

\section{E. Governmental Order n. 295/2002 of 19th March}

(Published in: “Diário da República nº 62/2002, Série I-B - Suplemento, Ministério da Indústria e Energia”)

Electrical energy production - Special regime Renewables - Hydro-electrical energy - Hydro power plants - Defines the procedures to obtain the necessary licences to electrical energy production by small hydro power plants. Revoke the Governmental Order n. 445/98, of 8th July.

\section{F. Despatch n. 6993/2002 of 15th of March}

(Published in: “Diário da República n 79/2002, Série II, Ministério da Indústria e Energia”) 
Electrical energy production - Special regimen Renewable - Invoicing - Defines new methods for energy invoicing.

\section{G. Despatch n. 4451/2002 of 13th of February}

(Published in: “Diário da República nº 50/2002, Série II, Ministério da Indústria e Energia”)

Electrical energy production - Special regimen oRenewable - Clarifies the determination relative to the number of working hours, referred in n. 18, paragraph a) of annex II to the Decree-Law 168/99, of 18th May.

\section{H. Decree-Law n. 339-C/2001 of 29th December}

(Published in: "Diário da República n 300/2001, Série I-A - Suplemento, Ministério da Indústria e Energia”)

Electrical energy production - special regimen Renewable - Modifies the Decree-Law n. 168/99, of 18th May, which revises the applicable regimen to the activity of electrical energy production, on the scope of independent electrical system.

A better exploitation of the Portuguese endogenous resources constitutes as an indispensable instrument to the prosecution of the govern energy policies, namely the reduction of the external energy dependency, and the diminution of pollutant emissions, particularly the ones which have relevant importance to the world climatic alterations.

In this context, the Portuguese government comprehends that is necessary to review the Decree-Law n. 189/88 of 27th May, introducing indispensable changes, and establishing a distinct remuneration in function of the used technology and of the exploration regimen, and attributing appropriate distinction to the technologies which, although emergent (like wave energy and photovoltaic energy), show a great potential at medium term, aiming this way, to create the indispensable conditions to the concreteness of exemplary projects. It is also recognized that the environmental contribution of the electrical power plants comprised by the present legislation is permanent, and so, it is not appropriate to establish any time limits to its accomplishment. Finally, it stipulates that the companies that own wind power plants have to pay a rent to the municipality where they are placed. That situation was not defined in the prior legislation.

\section{Decree-Law n. 312/2001 of 10th December}

(Published in: "Diário da República no 284/2001, Série I-A, Ministério da Indústria e Energia”)

Public service electrical system - Electro-producers Independent Electrical System - Electrical Energy Reception - It defines the management regimen of the electrical energy reception capacity on the public electrical system network services, coming from electro- producers of independent electrical systems.

\section{J. Resolution of Cabinet n. 154/2001 of 19th October}

(Published in: "Diário da República nº 243/2001, Série I-B, Ministério da Indústria e Energia”)

Approves the Energy Efficiency and Endogenous Energy Program (E4).

\section{K. Decree-Law n. 168/99 of 18th May}

(Published in: “Diário da República n 115/99, Série I-A, Ministério da Indústria e Energia”)

Electrical energy production - Special regimen Renewable - Alters some dispositions of Decree-Law n. 189/88 of 27th May, and proceed with its new publication. It has established the electrical energy production regimen by renewable energy independent producers.

In the last years, the energy sector, in a broad way, and the electric sector, in a particular way, have suffered deep transformations. Two of these transformations deserve special distinction. At one side, the creation of the energy internal market has conduct to the approval of directives that will establish deep liberal reforms on how this sector will operate. At the other side, the increasing preoccupation with the global environment defence will cause a bigger strangulation regarding the energy and the environment policies, in order to execute international compromises, like the limitations of gas emissions that cause the greenhouse effect, on result of the United Nations Board Convention implementation to climatic alterations and of the Kyoto Protocol.

The Portuguese government believes that these tendencies will be stronger in the future, and taking into account the obtained experience, it is justified to review the norms that are applicable to electrical energy production from renewable energy resources. This decree-law works in that revision, and it is worth to highlight:

- The complete changing of tariffs applicable to the selling of electrical energy produced from renewable resources, establishing the necessary principles to the quantification of the environment benefits brought by these power plants, allowing the implementation of tariffs habitually designated by the name "green tariffs". Thus, the energy produced from renewable sources has to the producer a better selling price than the energy produced from non-renewable sources.

-The reorganisation of the regulation process, concentrating in the diploma the general dispositions, the establishment of principles and the definition of rights and duties;

-The alteration of the mechanisms that lead to the definition of production power plants interconnection points, to assure a better transparency of procedures, and to guarantee a more complete treatment equity of the various promoters. 
The government is convict that the actual review of Decree-Law n. 189/88 of 27th May, with the new redaction given by Decree-Law n. 313/95 of 24th November, will give a new impulse to the development of renewable resources, contributing to a wider utilisation of energy endogenous sources and allowing a higher articulation between energy and environmental policies.

\section{Governmental Order n. 416/90, of 6th June}

(Published in: "Diário da República n 130/1990 Série I-A, Ministério da Indústria e Energia”)

Electrical energy production - Special regimen Renewable - Approves the contract-type for purchasing of electrical energy by EDP from independent producers, under the cover of Decree-Law n. 189/88 of 27th May.

\section{Decree-Law n. 189/98 of 27th of May}

(Published in: "Diário da República nº 123/88, Serial I-A, Ministério da Indústria e Energia”)

Electrical energy production - Special regimen Renewable - Establishs the electrical energy production regimen by independent renewable energy producers.

The optimised utilization of the Portuguese energy resources is a necessary line to development and economic progress. The various petrol impacts, with the aggravation of the Portuguese dependency in relation to the international energy market, must be remembered also when the international conjuncture regarding to energy is not problematic. At calm moments is necessary to know how to invest, appreciating the existent natural Portuguese resources that were not used, yet, and that can be used in a sustained way, without degrading the environment.

This decree-law has traduced on the legislative plan a policy for diminution of the Portuguese external dependency on primary energy, creating necessary conditions and establishing the adequate incentives to the promotion of endogenous resources utilization, in particular the renewable energies, the national fuels and the industrial, agricultural or urban wastes, and also the use of co-generation process. The publication of this diploma has enabled a strong development of electrical energy production by independent producers, giving value to the use of these resources.

\section{N. Decree-Law n. 313/95 of 24th November}

(Published in: "Diário da República n 272/95, Série I-A, Ministério da Indústria e Energia”)

This diploma establishes, on the scope of independent electrical system, the juridical regimen of activity for electrical energy production on hydroelectric power plants with installed apparent power up to $10 \mathrm{MVA}$, and the electrical energy production by other renewable energy sources. The definition of this regimen passes by the alteration of Decree-Law n. 189/88 of 27th May, eliminating the limits of installed power defined on its 1st article, with the exception of hydroelectric utilization, which continues limited to 10 MVA.

\section{O. Decree-Law n. 69/2000 of 3rd May}

(Published in: "Diário da República, Série I-A, Ministério da Indústria e Energia”)

The environmental impact evaluation is a fundamental preventive instrument on environmental and territory classification politics, and thus, it is recognized in the Environmental Basis Law n. 11/87 of 7th April. With this diploma, and in execution of what is disposed on articles 30th and 31st of the Environmental Basis Law, in the scope of the new environmental impact evaluation procedures, the decisions character is established, taking into account the importance of the energy production and of the environment protection.

\section{P. Decree-Law n. 292/2000 of 14th November}

(Published in: "Diário da República, Série I-A, Ministério da Indústria e Energia”)

This diploma intends to give answer to the sound pollution problem, with basis in the regimen defined in Environmental Basis Law. It defines applications, the interaction with others laws (like urbanization laws), the reinforcement of the preventive actuation principle, the adoption of specific planning figures, and the regulation of temporal activities that produce noise.

\section{Q. Decree-Law n. 239/97 of 9th September}

(Published in: "Diário da República, Série I-A, Ministério da Indústria e Energia”)

The adequate waste management is an urgent challenge to actual societies. In effect, the complexity and the gravity of the problems related to waste management actually have a so great importance that, it is no longer possible for the State to correspond to the fundamental task that the Portuguese Constitution attributes, in the sense of defending the nature and the environment, or preserving the natural resources, without structuring a consistent policy regarding residues, in a important position of a wider environment politics.

This relative to residues law defines the principle of that the waste is a responsibility of the one who produced it, and places an autonomous mechanism of previous authorisation of waste management operations, which cannot be confused with the simple licensing of the activities in which, sometimes, such operations are integrated.

On 1st chapter, 1st article, we can read: “The present diploma establishes the rules at which waste management is subject to, namely its recovery, transportation, storage, treatment, valorisation and elimination, in way that it does not constitute any danger or cause any damage to human wealth or to the environment”. 


\section{R. Decree-Law n. 273/98 of 2nd September}

(Published in: "Diário da República, Série I-A, Ministério da Indústria e Energia”)

This decree-law defines the existent legislative board and operates the transposition to internal right of directive n. 94/67/CE of the council of 16th December 1994, relative to dangerous waste incineration, changing the 11th part 2 of annex VI of the governmental order n. 286/93, of 12th Mars, in form to be transported the dispositions in respect to atmospheric pollution.

\section{S. Decree-Law n. 40/90 of 6th February}

(Published in: "Diário da República, Série I-A, Ministério da Indústria e Energia”)

This regulation (Regulation of the Building Thermal Behaviour Characteristics - "Regulamento das Características de Comportamento Térmico dos Edifícios” - RCCTE) defines a first regulation basis that aims the improvement of the thermal quality of buildings, in the sense of "improvement of the comfort's conditions without an increase in the energy use”. This regulation, although considered a moderate one in terms of its demands, has had a significant impact in the form the buildings are constructed in Portugal. At present, 13 years after its publication, the majority of the new buildings use thermal isolations in walls and double glass in windows, and the future owners already ask for these items.

\section{T. Decree-Law n. $118 / 98$ of 7th May}

(Published in: “Diário da República n 105/98, Série I-A, Ministério da Indústria e Energia”)

This regulation (Regulation of Climatic Energy System in Buildings - "Regulamento dos Sistemas Energéticos de Climatização em Edifícios - RSECE) fundamentally aims the improvement of the efficiency in climatic energy systems of buildings. This regulation establishes a set of rules in order that "the demands for comfort and environmental quality inside the buildings can be assured in efficient conditions regarding the expended energy”.

\section{U. Governmental Order n. 1058/94 of 2nd December}

(Published in: "Diário da República, Série I-A, Ministério da Indústria e Energia”)

The Governmental Order n. 286/93 of 12th Mars, edited under the cover of Decree-Law n. 352/90 of 9th November, has fixed the maximum and the general values on the environment for the Sulphur Dioxide, the particles in suspension, the Nitrogen Dioxide and the Carbon Monoxide, as well as the maximum values for the Lead and the guide values for the Ozone.

The experiences acquired during the execution period of this governmental order advises the introduction of some adjustments, particularly regarding to the inclusion of an item on its annex VI that is applicable to the cogeneration systems.

\section{Incentives: Support Mechanisms for Investment and for Acquisition of Renewable Energy Equipments}

There are two support mechanisms in Portugal for investment and acquisition of renewable energy equipments:

- A juridical regimen that establishes a differentiated tariff for the production of electricity from renewable energy sources (Decree-Law n. 168/99 of 18th May, published in "Diário da República n. 115/99, Série I-A", and recently reviewd by Decree-Law n. 339C/2001 of 29th December, published in "Diário da República n. 300, Série I-A - Suplemento”);

-An incentive system to support the investments in projects of energy production that use new and renewable energy sources, and the rational utilization of energy. This system was created in the scope of the "Terceiro Quadro Comunitário de Apoio para Portugal" (QCA III), and was named "Medida de Apoio ao Aproveitamento do Potencial Energético e da Racionalização de Consumos” (MAPE). This incentive system is regulated by the Governmental Order n. 383/2002 of 10th April, published in "Diário da República n. 84/2002, Série I-B”, and it will be applicable between the years 2000 and 2006.

It is also important to refer the existence of fiscal incentive for the acquisition of renewable energy equipments in Portugal: a $12 \%$ VAT tax reduction and the deduction of a part of the investment in the annual taxation (IRS).

Through the Governmental Order n. 725/91 of 29th July, it was proceeded a delimitation to stimulus of the renewable energy utilisation by domestic users, through the attribution of respective fiscal incentives, which refer to forms of renewable Energy like the direct or diffuse solar radiation, the energy contained on wood or agricultural residues, and the wind energy.

The present article 85 ("Encargos com Imóveis e Equipamentos de Energia Renovável”) has come to replace the article $80 \mathrm{H}$ ("Dedução à Colecta dos Encargos com Imóveis"), and the article 80 L ("Dedução à Colecta dos Encargos com Equipamentos Novos de Energia Renovável”). This article announces that: it is possible to deduct at collect, as long as not susceptible of been considered costs of category B, $30 \%$ of the costs used for the acquisition of new renewable energy equipments, and for the production of electrical and/or thermal energy (co-generation) using micro turbines with a power inferior to $100 \mathrm{~kW}$, which consume natural gas, and including complementary equipments that are indispensable for the operation of the energy production system, with costs limited to $€ 700.00$. (Decree-Law n. 109/2001 of 27th December). 


\section{Suggestions}

Next are presented some suggestions that could lead to an important increase in renewable energy production in Portugal, namely from wind power and photovoltaic small power plants.

Portugal has good levels of solar radiation all over the country, and also has good mean values for wind speed in considerable areas, like its $800 \mathrm{~km}$ of west coast. The production of electrical energy from medium and small wind and photovoltaic power plants can be a solution to mitigate the serious Portuguese energy dependency from other countries. Besides, the energy production from these renewable and "clean" energy sources would help Portugal to acomplish the commitments that were made regarding the production of non-pollutant renewable energy (the Kyoto Protocol, which was signed by all European countries impose that).

A large number of medium and small power plants can produce as much energy as a huge one. Besides, with medium and small power plants there is no needing to build new electrical transmission power lines, since the energy production is not concentrated, but distributed.

However, the medium and small renewable energy power plants would have to accomplish present legislation regarding "reactive energy" production during peak power consumption period, and besides, they would have to assure power quality levels. With the development that Electrical Engineering, and the area of Power Electronics in particular, have experienced in the last years, it is possible to present suitable and inexpensive solutions to these demands.

One of the problems related to the production of renewable energy consists in the fact that, by legislation all energy must be delivered along with $40 \%$ of "reactive energy”, during the peak power consumption period. Using a power electronics converter (a current controlled voltage source inverter) it is possible to inject the energy produced by the medium/small wind power or photovoltaic panels plants in the electrical power grid, along with as much "reactive energy" as necessary, with affordable costs (see Figure 3). Besides, this power electronics converter injects sinusoidal currents in the power grid, and so, the power quality of the produced electrical energy is guaranteed.

The basic operation idea for the medium and small renewable energy power plants consists in the fact that a significant part of the energy produced by these plants will be consumed at the point of production, by the industry, commerce building or residence where the energy was produced. However, always that production is greater than consumption, the exceeding energy has to be sent to the electrical power grid. So, the power plant can work as an energy producer or as a consumer. This kind of operation demands for a reversible energy meter should, so that it would be registered the consumption of energy from the electrical power grid, or the delivery of energy to the power grid.
The use of reversible energy meters is fundamental to the success of the proposed medium and small renewable energy power plants, since this solution is interesting when the industrial, commercial or residential consumer can reduce the costs with electricity, because them produce a part of the energy they need, and they can sell energy when they produce more energy than what they need (along the day or along the week, the consumption and the production of energy may vary according to the user necessity and the amount of wind and solar radiation).

The quality of the produced electrical energy can be assured with the use power quality monitors, which will experience drastic cost reduction in the forthcoming years.

To acomplish these suggestions, it would be necessary a revision or elaboration of new legislation that could facilitate, encourage and finance the implementation of small and medium size renewable energy power plants in industries, commerce buildings and residences.

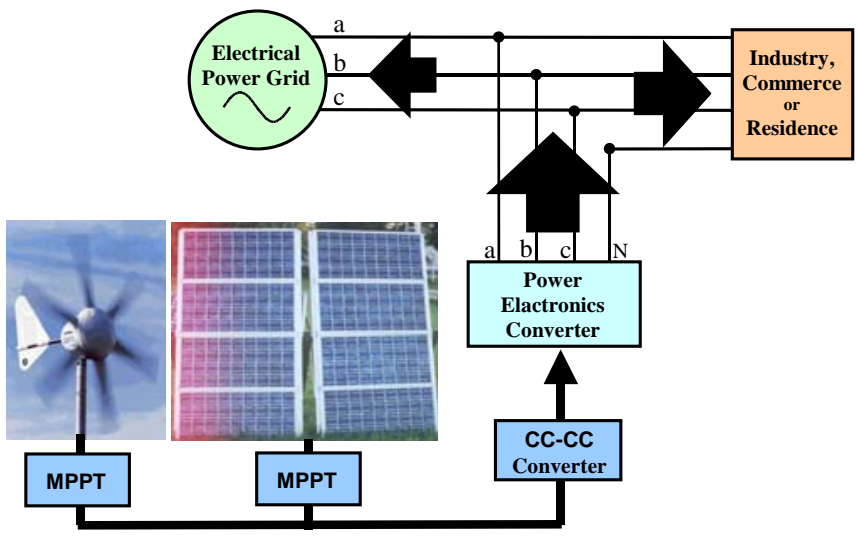

Fig. 3. Suggestion for medium/small renewable energy production power plants.

\section{Conclusion}

The most important Portuguese legislation regarding electrical energy production using renewable resources is the Decree-Law n. 189/98 of 27th May, with redaction given by Decree-Law n. 168/99 of 18th May (which makes the republication), modified by Decree-Law n. 312/2001 of 10th December, and by Decree-Law n. 339-C/2001 of 29th December. In the scope of this legislations is also included the utilization of industrial, agricultural or urban waste.

Concerning environmental questions, in what depends on the nature, dimension and location of the installations, its important to refer the following topics and related Portuguese legislations:

- Environmental impact: Decree-Law n. 69/2000 of 3rd May;

- General sound noise regulation: Decree-Law n. 292/2002 of 14th November; 
-Licensing for small hydroelectric power plants: Governmental order n. 295/2002 of 19th March;

- Pollutant emissions: Governmental Order n. 1058/94 of 2nd December and Governmental order n. 268/93, of 19th March;

- Authorization for burning waste: Decree-Law n. 239/97 of 9th September and Decree-Law n. 273/98 of 2nd September.

Nowadays, with the development of Power Electronics, it is possible to have solutions to the production of renewable energy production based in medium and small power plants. Portugal presents good conditions to the implementation of a large number of these power plants, based on wind power and photovoltaic energy.

\section{Acknowledgements}

The authors are grateful to FCT (Fundação para a Ciência e a Tecnologia), project funding POCTI/ESE/41170/2001.

\section{References}

[1] Diário da República nº 115/99, Série I-A, Ministério da Indústria e Energia, Decreto-lei nº 168/99.

[2] Diário da República n ${ }^{\circ}$ 123/88, Série I-A, Ministério da Indústria e Energia, Decreto-lei nº 189/88.

[3] Diário da República $n^{0}$ 84/2002, Série I-B, Ministério da Indústria e Energia, Portaria $\mathrm{n}^{\circ}$ 383/2002.

[4] Diário da República no 300/2001, Série I-A Suplemento, Ministério da Indústria e Energia, Decreto-lei no 339-C/2001.
[5] Diário da República $n^{\circ}$ 284/2001, Série I-A, Ministério da Indústria e Energia, Decreto-lei $\mathrm{n}^{\mathrm{o}}$ 312/2001.

[6] Diário da República $\mathrm{n}^{\circ}$ 66/2002, Série I-B Suplemento, Ministério da Indústria e Energia, Decreto-lei no 295/2002.

[7] Diário da República $n^{\circ}$ 198/2001, Série II, Ministério da Indústria e Energia, Despacho $\mathrm{n}^{\mathrm{o}}$ 22044/2002 (2 $2^{\mathrm{a}}$ série).

[8] Diário da República $n^{\circ}$ 149/2002, Série I-B, Ministério da Indústria e Energia, Portaria $\mathrm{n}^{\circ}$ 764/2002 .

[9] Diário da República $n^{0}$ 103/2002, Série II, Ministério da Indústria e Energia, Despacho $\mathrm{n}^{\circ}$ 9148/2002 .

[10] Diário da República $n^{\circ}$ 66/2002, Série I-B, Ministério da Indústria e Energia, Portaria $\mathrm{n}^{\mathrm{o}}$ 295/2002 .

[11] Diário da República nº 79/2002, Série II, Ministério da Indústria e Energia, Despacho nº 6993/2002 .

[12] Diário da República nº 50/2002, Série II, Ministério da Indústria e Energia, Despacho no 4451/2002 .

[13] Diário da República $n^{\circ}$ 243/2001, Série I-B, Ministério da Indústria e Energia, Resolução do Conselho de Ministros no 154/2001.

[14] Diário da República no 130/1990, Série I-A, Ministério da Indústria e Energia, Portaria $\mathrm{n}^{\circ}$ 416/1990 .

[15] J. L. Afonso, C. Couto, J. S. Martins, "Active Filters with Control Based on the p-q Theory", IEEE Industrial Electronics Society Newsletter, vol. 47, n. 3, Sept. 2000, pp. 5-10. 